\title{
The Cultural History MA at the University of Aberdeen, 1986-2011: a personal reflection
}

\author{
NICK FISHER
}

The undergraduate programme in cultural history at the University of Aberdeen began almost twenty-five years ago, but is now being discontinued. The last cultural history students will graduate next year. It is of course hard to be cheerful when writing about the last days of a programme to which so many people contributed so much care and effort, but my abiding memory will always be of the enormous enjoyment that many of us got from teaching cultural history in the early days, in the growth part of the curve, and at its peak. We all learned so much that we would otherwise not have been able to.

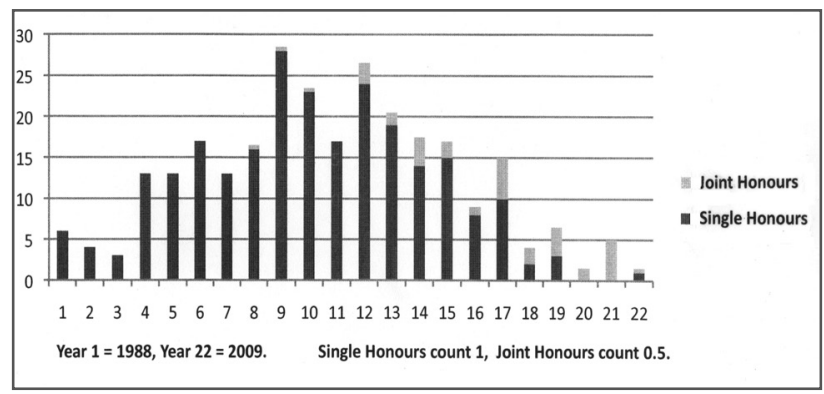

Table 1: Aberdeen Cultural History Graduates 1988-2009

My younger colleagues who have kept the flame burning in the period of decline assure me that this is still very much the case: the teaching is enormously 
rewarding. From the start, cultural history was a liberation from conventional disciplinary limits. Moreover, it served as a much-needed morale booster in the face of the university-wide depression caused by the Thatcher government's cuts to university funding in the 1980s, which had a severe effect on Aberdeen.

We need a word about the context, and about how the most conservative and geographically isolated of the ancient Scottish universities came to start such a unique experiment. Aberdeen University, founded in 1495, was for most of the twentieth century an ordinary Scottish university. This means among other things that the students entered about a year younger than their English counterparts, and that they were admitted not to departments but rather to faculties (Arts, Divinity, Medicine, Science, Law), which has implications for my story: it is much easier for Scottish students than English to change their intended direction once they have sampled one or two years of university study. Moreover, the broader four-year Scottish honours degree is different from a three-year English degree. And when after the Second World War the other Scottish universities, St Andrews, Glasgow, and Edinburgh were forced by the conditions attached to government funding to become more aware of international comparisons and competition, Aberdeen self-consciously remained the most traditionally Scottish of the universities. It was also rather small, with 2500 students in 1960.

The 1960s saw a period of huge expansion in British education, with the foundation of many new universities. In search of the economic benefits of a more educated population, student numbers were intended to more than double in the fifteen years from 1962, facilitated by generous student grants to all who qualified for university entrance. In Scotland the number of universities was increased from four to eight. Of the older universities, Aberdeen was particularly singled out for growth. Glasgow and Edinburgh were thought by the administrators of the Scottish Education Department to be big enough already, while the little city of St Andrews was considered unable to cope with a large increase in student numbers. The target numbers for Aberdeen were raised and raised again, from the actual 2500 in 1960 to targets of 4500 for 1967, of 8180 for 1976, and finally of 10.500 for 1981 . These planned expansions were intended roughly to parallel the physical and economic growth of the City of Aberdeen as a result of the discovery of North Sea oil. With the encouragement, indeed the insistence, of the University Grants Committee, the distributor of British government funds to universities, the University of Aberdeen set about building the classrooms and student residences, and hiring the staff, that would be required for all these new students. Unfortunately, nobody told the students that they were expected in Aberdeen, and there were no efficient mechanisms for directing student choice. When I was appointed in 1976, the student population was around 5500, not the 
intended 8180. As a result, when the economic crisis for universities came in 1981, Aberdeen was found to be over-provided with both buildings and staff; and it had too many small and thus supposedly inefficient departments, such as my own, History and Philosophy of Science, with its staff of 3. The cut in Aberdeen's government grant announced that summer was 19\%, compared with a national average of $11 \%$. The University's response was to announce 169 academic staff redundancies, compulsory if necessary, including all the inefficient little departments.

A vigorous academic defence was led by mass meetings of the lecturers' union, the Aberdeen Association of University Teachers (AAUT). The University meanwhile offered quite generous compensation packages for early retirement, and by April it was clear that enough academics had accepted these packages, or had left for other universities less badly affected, so that the required savings in staff costs had been achieved, and the threat of further sackings and closures was formally lifted. But it has to be said that the radicalisation and the militancy of the staff that arose during that year ensured that their attitudes towards the University, including feelings of loyalty and trust, were never the same again.

The immediate outlook for the future of teaching and learning at the University was now rather bleak. After all the work that had gone in to reducing staff costs, it was clear that it would be some time before the flow of new young lecturers could start again. How then could innovation in teaching, at little or no cost, be encouraged? One individual who gave this much thought was Dr. Judith Hook of the History Department. She was a scholar of $17^{\text {th }}$ century English art, and of the more general history - indeed the cultural history - of Renaissance Italy. Judith's work culminated in the publication of her biography of Lorenzo de' Medici in 1984. She had been particularly active in the struggles of the AAUT, when she and I had been close comrades in arms. She was forever dreaming up new schemes, often of doubtful practicality. In early 1984 she had heard that the new British television channel, Channel 4, was seeking suggestions for new programmes, possibly some of them academic. She sat at my kitchen table discussing a proposal for an intellectual history series. In Britain we talk about plans being made on the back of an envelope; if one is talking about politics or about budgetary planning, it is rather rude and dismissive to say this. But some important plans start on the backs of envelopes, and here is the beginning of Aberdeen's cultural history. 

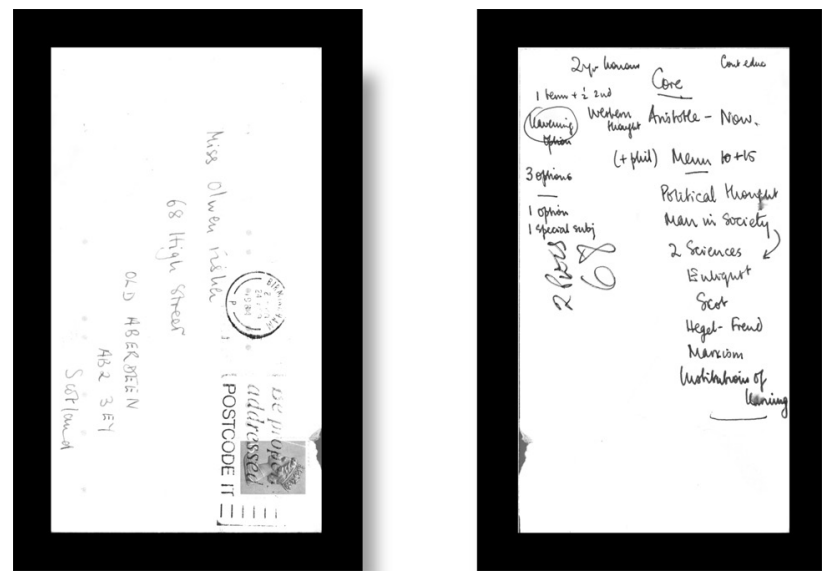

Table 2

I can't really make much sense of it after 26 years - and this is not remotely what happened. Channel 4 would certainly not have thought much of it. (Channel 4 has found its niche as the British home of Big Brother, and intellectual history would be entirely alien to it.) Fortunately Judith also pursued these ideas within the University, and towards the end of academic year 1983-84 organised a meeting with members of the History Department and others such as myself who had an interest in interdisciplinary teaching. That summer Judith went to Florence as usual for her research, and in August she suddenly died there of a brain haemorrhage.

Partly in memory of Judith, her colleagues in the History Department sought to carry her exploration further. The immediate occasion for the resumption of discussions was a visit by the cultural historian Roy Porter to give a lecture to the Department in March 1985. In conversation afterwards, he was most encouraging of our efforts at interdisciplinary teaching. A number of us took these forward over the summer and autumn. In the summer two significant decisions were made: to spread the invitation to talk as widely as possible by word of mouth, and to invite Joan Pittock Wesson of the English Department, who had organised a successful series of interdisciplinary seminars in the 1970s, to become convenor of the group. By the autumn intellectual history had become cultural history, as both a more inclusive approach and more widely interdisciplinary - not to mention more modern - and detailed planning for an honours course in cultural history had begun. When the course proposal was submitted to the Arts Faculty Planning Committee in December, it was turned down on the grounds that a time of financial stringency was no time to be experimenting with 
new ways of teaching; this was of course the exact opposite of our argument that it was precisely because of the financial constraints that one had to come up with new ways of doing things.

So we appealed to the full Arts Faculty meeting against this initial refusal, and we won the vote, which allowed us to proceed. Apart from the intellectual arguments for the proposed cultural history course, and the emotional arguments in memory of Judith Hook, there were three other main reasons for this turnaround. The practical argument was that we had so many possible contributors that no one of us would be overburdened by the additional teaching. Translated into political terms, this same argument about numbers meant that the group and its many friends throughout the Faculty could attract enough votes to win. And the clinching political fact was that after the radical struggles of the early 1980s, nobody wanted to be told what they should do or what they should think by figures of authority such as deans and their planning committees.

Let me outline the normal structure of an arts honours degree that we were threatening to subvert. An Aberdeen arts student would typically take three courses in year 1, two in year 2, and then in years 3 and 4 (junior and senior honours) would specialise in either those same two disciplines (joint honours), or only one of them (single honours). The overall menu was not an entirely free choice: there were rules governing permitted combinations of disciplines, and there were particular prerequisites for certain courses. And until the early 1970s there had been a general prerequisite that all arts students had to take at least one course in philosophy, once a characteristic of all Scottish arts degrees. The degree structure for science students was comparable, except that single honours was the norm. Overall, the expectation was that candidates for an honours degree, whether single or joint, would be prepared for their honours classes by two years of prior study in their discipline(s).

What we cultural historians were proposing was an Honours degree which assumed no earlier preparation, and would thus begin from zero in Year 3. This was entirely anomalous. It was proposed that we took any student with the standard number of passes in earlier courses, including students from the Science Faculty (or elsewhere). We would teach them intensively a basic course in the cultural history of north-west Europe from the Enlightenment and the French Revolution, through the romanticism and nationalism of the $19^{\text {th }}$ century, up to the onset of the First World War, all over 24 weeks. This would be preparatory to more specialist courses in the senior honours year.

As students were considering their futures towards the end of academic year 1985-86, posters were circulated inviting any students interested in the new cultural history degree to contact the Convenor or any member of the core group. 
(It should be emphasised that altogether many more than the ten staff members named on the poster were involved.) In October 1986 our first intake was six students.

They took a single course which had 4-6 lectures a week and one or two seminars. One of the seminars would discuss the week's key text, an insistence from members of the English department. The first text was Francis Bacon's New Atlantis as part of the $17^{\text {th }}$ century background to the Enlightenment. Later in the year the concept of text broadened to include several non-literary works; Haydn's Creation as an Enlightenment text was one; the Great Exhibition of 1851 in London was another (the latter has been my chief personal research interest ever since). In keeping with the interdisciplinary nature of the course, two or sometimes even three members of staff participated in the seminars, and all for six students! This generosity could not last for very long, although many years later there were still a few seminars with staff from two different departments. The emphasis throughout was on cultural interconnexions, easily enough traced in the European Enlightenment, but also to be found throughout the $19^{\text {th }}$ century.

Another feature of the cultural history teaching was that it involved more than the regular teaching staff. The University Archivist, Colin McLaren, gave a series of lectures on the cultural history of libraries. Other recruits included a second librarian whose $\mathrm{PhD}$ dissertation had been on the history of the book trade, the curator of the University's anthropological museum, the University's public relations officer who had previously worked for Scottish Opera, and a careers adviser who had an interest in the notion of the wilderness. People such as these welcomed the opportunity to teach their special interests that they would not normally have had. All at different times added to the richness and diversity of the cultural history course. (It is perhaps no coincidence that several of our students went on to work in libraries or museums.)

It should be said that in the tradition of British empiricism, the Aberdeen student's conception of cultural history was not theory-based, but was allowed to grow by slow empirical example. Such theory as we taught came later, and built on this empirical base. One result of this was an almost universal feeling among the students, maybe half-way through the introductory junior honours year, of being lost in a forest of disconnected information. "What is this cultural history?" they would ask. This feeling of dislocation would eventually pass, as group consciousness and solidarity reached some kind of an answer, allowing the students to make the connexions. Even among the small numbers of our initial intakes, esprit de corps, group solidarity, was always a striking feature. 
In senior honours, our initial six students found the same generosity of staff teaching time which would be unthinkable today: eight optional courses for six students:

\begin{tabular}{|llc|}
\hline M.A. WITH HONOURS IN CULTURAL HISTORY: Senior Honours 1987-8 & \\
Special Options: & Students \\
& & 2 \\
Death and the Family & Andrew Wear & 2 \\
Darwin and Victorian Thought & Robin Gilmour & 1 \\
Ideas of Language & David Cram & 1 \\
Russia and America & Paul Dukes & 2 \\
Structuralism and after & Michael Spiller & 1 \\
Commerce and Art & David Irwin & 2 \\
Childhood & Joan Pittock Wesson & 1 \\
The History of Sexuality & Mike Hepworth and David Oldman & \\
& & \\
Reading lists should be obtained from tutors before the end of this term. & \\
\hline
\end{tabular}

Table 3

And at the end of their fourth year, they took all their final exams over a few days, as was then the practice:

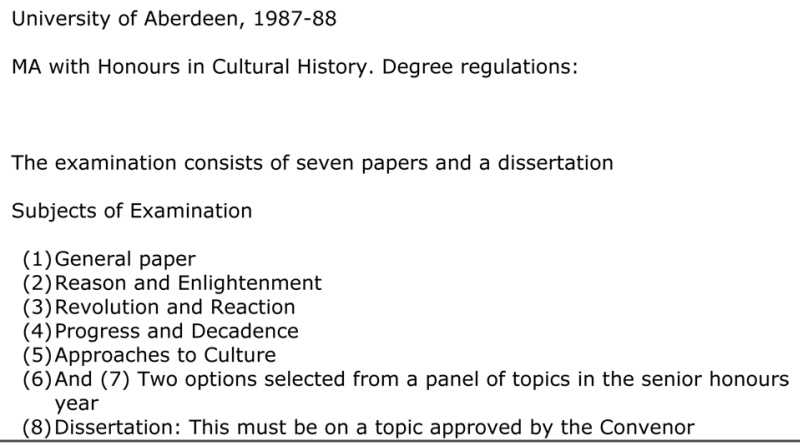

\section{Table 4}

That first year, two of our six students achieved first class honours degrees.

I should briefly mention another activity that helped to forge a sense of common identity among the staff, and to put Aberdeen's cultural history on the map. Four successful international conferences were held in the summers of 1987 to 1990.

For a while it looked as if our enjoyment of the teaching was going to have diminishing, perhaps terminally diminishing, returns. Our class of six was fol- 
lowed by four, and then by three. In a naked attempt at recruitment we proposed a second-year feeder course from 1988, but this was turned down-this time with no hope of appeal. But suddenly in 1989 recruitment took off, presumably due to favourable recommendations among the students: we had thirteen, thirteen, seventeen. By our ninth year of operation, we had twenty-nine graduates.

What sort of students did we get? Those with the initiative and determination to change from their original direction. Later, in the 90s, as the University made more and more effort to recruit mature students (a technical term meaning those more than 23 years old when they enter) we got a disproportionate number of those. Mature students, who often turn to university to change the direction of a life they have come to see as unsatisfying, tend to opt for courses that offer cultural enrichment rather than the financial riches held out by vocational courses. At least one of our adult students used cultural history to rebuild his life more profoundly. On 6 July 1988 the Piper Alpha oil platform off Aberdeen exploded killing 167 workers; there were 59 survivors. One of these, Bob Ballantyne, entered the University as a mature student and chose to graduate in cultural history. Some time later, when all of our courses had been modularised (that is, they had become self-contained and graded at the end of each course, so that one could take individual cultural history courses without signing up for the whole degree), we also got much more than our share of visiting Europeans and Americans, attracted by unusual courses they could not get at home. And over the years there was roughly a two to one ratio of women to men among cultural history graduates.

A major change which accompanied our success in the 1990s was the decline of our pool of teachers. It almost seemed as if staff numbers were inversely proportional to our success in attracting students. The fall-off in contributors might have been due to increasing teaching duties in a home department, or transfer elsewhere in Britain, or the non-renewal of a temporary contract, or retirement, or death -all of which affected individuals among our staff. Or someone who had given a few lectures over the years would go on research leave, and on return would be unwilling to pick up the responsibility again. Or a contributor who had at the beginning given ten or twelve lectures a year was now down to two or three. By the late 1990s, more than half the teaching was done by four or five core staff, and wider contributions had become more the exception than the norm.

But there were other changes in the 1990s which may have contributed to this situation. In 1992, due to our growing numbers of students, Cultural History was for the first time granted the status of an independent academic department, and the Convenor given a formal part-time appointment as Head of Depart- 
ment. During the following year, the first appointment of a full-time Lecturer in Cultural History was made: this was a cultural anthropologist, who planned and introduced a successful second-year feeder course, as well as a popular senior honours option. The new department was housed in a renovated ancient building away from the main campus.

After two years this arrangement was subjected to an Internal Teaching Review, an inquisition based on the government's official Teaching Quality Assessment, and like the latter requiring a mountain of paper describing every course in the smallest detail. The proceedings of the review were notable for the extremely strong support for our teaching given by our students, and also by our external examiners from past years such as Roy Porter and Peter Burke. The result of the inquisition was that-for various reasons which I need not go in to- the experiment of departmental status for cultural history was judged not to be a success. The group was to be moved back on campus to lessen any tendency of the students to consider themselves special and apart, and the administration of the group was to be under the supervision of another established department. Philosophy was chosen, chiefly in order to avoid the big guns of History and English, both of which tended to be hostile to cultural history. Powerful individuals in those two departments regarded cultural history not only as inferior as a discipline, but also as a seducer of their intended students. On the other hand, the Teaching Review recommended that full time appointments to cultural history should be extended. In early 1995 I was appointed Director, and my colleague Bill Scott, historian of the French Revolution, was made full-time Senior Lecturer, in addition to our anthropologist Lecturer. We were also given a third of the time of a Teaching Fellow, Leigh Clayton (a Lecturer in all but name, who did not have a Lecturer's research commitment), and were further supported by Peter McCaffery, a retired sociologist who was paid by the hour. Partly as a result of its success, the cultural history group was becoming very different from the wide circle of enthusiastic volunteers who had initiated it.

Cultural history flourished at this time, under the most sympathetic dean we ever encountered. Now that we had secure staffing, we were able from 1996 to introduce an additional second-year course, The Culture of the human and natural environment, which complemented the recruiting effects of our introduction to anthropology.

At the same time, the compulsory core of courses was maintained, and indeed extended to a compulsory course on the culture of the $20^{\text {th }}$ century to be taken in fourth year. So unlike in all the other programmes in the Arts Faculty, our students were allowed a free choice only in their two optional courses. Nobody seemed to mind this lack of choice-except perhaps members of other 
departments, who objected that cultural history seemed always to be special case, a constant anomaly.

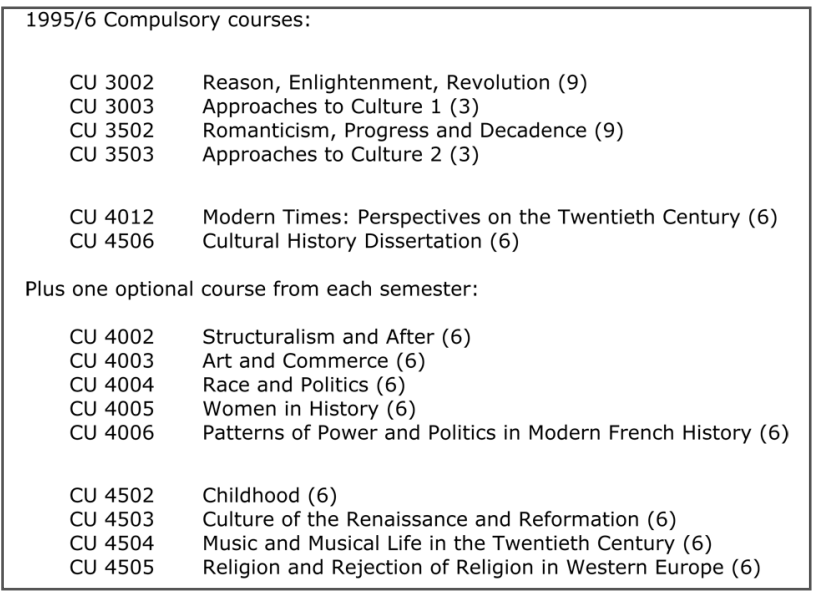

\section{Table 5}

I have already said that at this period of our greatest numbers of students at all three levels, the bulk of the teaching was done by four or five of us, of whom three were full time. We were desperately overworked, with ratios of students to staff which would not have been tolerated in infant school, but a now unsympathetic dean was deaf to pleas for more staff. It has been a feature of British universities since the financial crises of the 1980s and a political call for public accountability that a supposedly accurate price is put on everything from paper clips to staff salaries to tractors for the playing fields. When I was director of the programme in 1998, the figures of income and expenditure showed that cultural history's student numbers were bringing in about $£ 200.000$, but our costs were less than $£ 100.000$; we were thus subsidising the rest of the Arts Faculty. I argued strongly for the appointment of two new staff members to relieve the teaching overload, but was told that these figures were merely notional. Four years later, equally notional figures were used the other way to justify the dismantling of the programme. "Cultural History is losing money," said the new dean, without providing any evidence. Now the figures were considered not notional, but the basis for real cuts.

One other result of the success of our two second-year courses was that these were now made prerequisites for entry into cultural history honours, thus making it like all other disciplines in the Faculty, and removing an anomaly which would upset any tidy-minded dean. This meant that we could no longer freely take in refugees from English or History or wherever who had become unhappy 
with their original intentions. Recruitment to the honours years did suffer, although not radically so at first.

One very obvious problem with cultural history teaching being in the hands of just a few teachers was that it became vulnerable to any change in personnel. My contract was not renewed in 1999, and my colleague Bill Scott retired a year later. We were replaced by new appointments from outside, but this could be tricky. To go back a few years, before I was made Director the post had been advertised externally, but it was found that the outside candidates were not sufficiently in tune with the existing group. Later, when replacements for myself and Bill Scott came to be appointed, their expertise naturally differed from ours, and so the core courses had to change. Leigh Clayton, our teaching fellow, who was now essentially full time in Cultural History, was particularly helpful in keeping the $19^{\text {th }}$ - and $20^{\text {th }}$-century core courses going, but the Enlightenment course, which since the very start in 1986 had been the bedrock of our programme, was replaced in 2001 by a less focused course with a much longer timespan, Continuity and change, 1500-1800.

The real bombshell came in 2002, when as I have already said the Dean of Arts claimed that Cultural History was making a loss, and dissolved the group. Our anthropologist who had been my successor as Director moved to the new Anthropology Department. Leigh Clayton's contract was not renewed. There is a shameful suspicion that this was because after so many years teaching on fixed-term contracts, it was a legal requirement that at the next renewal the University had to give her a permanent contract. Rainer Brömer, who had been hired as a one-year replacement and kept on for a second year, was also "let go", to use the euphemism. The remaining staff joined the History Department, with my successor as historian of science, Ben Marsden, as convenor of the cultural history programme. With these changes, and especially the sackings, the core of the programme fell apart. The $19^{\text {th }}$ - and $20^{\text {th }}$-century courses were immediately abandoned. The second-year courses did not long survive, and the prerequisites for cultural history honours became an unheard-of combination of history and religious studies and anthropology courses.

The effects on student recruitment and morale were obvious. The changes were announced before the end of summer 2002. Many of the existing junior honours students simply disappeared, and did not return for their senior honours year.

A University-wide reorganization followed a year later. Every seven years or so Aberdeen University is subjected to a major structural change, intended to transform it into the hottest university outside London, Oxford, and Cambridge. Somehow this never quite seems to work as it should. The big idea in 2003 was the abolition of faculties and departments, and the establishment of colleges and 
schools. History and Art History and Divinity and Philosophy became a single school, resulting in a final loss of autonomy for what little remained of cultural history. Despite his heroic efforts to keep the distinctive degree going, Ben Marsden's position as convenor of the cultural history programme was abolished, and, as another example, the approval of dissertation topics for cultural history students was passed to the historian responsible for the history dissertations. He was described to me by one colleague as clearly an enemy of cultural history.

As there came to be less and less that was distinctive about cultural history courses, so students combined them more and more with other disciplines as joint honours. Early on, we had been able to resist attempts to bring us in to joint honours combinations by using the argument that the core programme could not be broken into small parts suitable for combination, and in any case Cultural History was the archetypal joint honours course, since it encompassed so many diverse disciplines. As a result the great majority of the cultural history graduates over the first fifteen years, during the up curve, did single honours, whereas almost all of the recent graduates have done joint.

From the other side, the side of the need for homogenization, of the avoidance of anomaly, comes the argument from historians that "We're all cultural historians now." I suppose a few members of our history departments are using approaches that were once the province of the cultural historian. But they are no more true teachers of cultural history than American teachers of English literature who were so excited by what they called "the new historicism", otherwise known as old cultural history.

And now the end is in sight at Aberdeen. But how good it was while it lasted! And yet all is not quite lost. A phoenix rises from the ashes. Due to the energy of my colleagues David Smith, Ben Marsden, Ralph O'Connor, and others, an international conference to celebrate 21 years of cultural history at Aberdeen was held in July 2007. Out of that grew the International Society for Cultural History, with its own successful conferences at Ghent and Brisbane (and now Turku). And the international network so established has led indirectly to this conference in Mainz. I gather also from David that there is now the possibility of an international journal of cultural history. And back in Aberdeen he runs a successful continuing cultural history seminar series.

This has been a very personal and inevitably partial account of our experience in Aberdeen, where we were able to build a cultural history programme from nothing, initially at very little cost. Different parts of that experience will resonate with different people. Some of it will not be applicable outside Scotland at all. But I hope that what I have said will be of interest and of some use to you all. 